\title{
Using Combined Metadata Sources to Visualize a Small Library (OBL's English Language Books)
}

\section{Peter A. Hook}

School of Library and Information Science, Wayne State University, 106 Kresge Library, Detroit, MI 48202. Office phone: 888-497-8754 ext. 712. Cellular phone: 812-345-4235 Fax: 313-577-7563. Email: peter.hook@wayne.edu

\section{Amanda Gantchev}

School of Library and Information Science, Wayne State University, 106 Kresge Library, Detroit, MI 48202. E-mail: amanda.gantchev@wayne.edu

\begin{abstract}
Data from multiple knowledge organization systems are combined to provide a global overview of the content holdings of a small personal library. Subject headings and classification data are used to effectively map the combined book and topic space of the library. While harvested and manipulated by hand, the work reveals issues and potential solutions when using automated techniques to produce topic maps of much larger libraries. The small library visualized consists of the thirty-nine, digital, English language books found in the Osama Bin Laden (OBL) compound in Abbottabad, Pakistan upon his death. As this list of books has garnered considerable media attention, it is worth providing a visual overview of the subject content of these books - some of which is not readily apparent from the titles. Metadata from subject headings and classification numbers was combined to create book-subject maps. Tree maps of the classification data were also produced. The books contain 328 subject headings. In order to enhance the base map with meaningful thematic overlay, library holding count data was also harvested (and aggregated from duplicates). This additional data revealed the relative scarcity or popularity of individual books.
\end{abstract}

\footnotetext{
Introduction

Information Visualization has the potential to reveal the structure, dynamics, properties, and idiosyncrasies of knowledge organization systems (see (Börner et al., 2007)). Visualization also has the ability to utilize data from multiple knowledge organization systems to provide global overviews of the content holdings of libraries. The authors use a small, personal library, to demonstrate proof of concepts related to the combined use of subject headings and classification data to effectively map books in topic space. While harvested and manipulated by hand, the work reveals issues and potential solutions when using automated techniques to produce content maps of much larger libraries.
}

\section{Related Work}

Knowledge organization systems (KOS's) have been used to visually enhance the result list in a literature database search (Doms \& Schroeder, 2005; "gopubmed,"). Also, KOS's have themselves been visualized. LCSH Galaxy utilized the subject authority records for the Library of Congress Subject Headings to visualize the node-link network of its syndetic structure (Gleich, 2009; Stanford University's 
CADS \& LOC's Office of Strategic Initatives, 2009a). Absent other associative hooks to make the content manageable, the group limited the subject headings shown to "only headings used over 500 times or that have more than 150 related headings" (Stanford University's CADS \& LOC's Office of Strategic Initatives, 2009b). Polley and Marshall used LCSH data and node-link diagrams to visualize the circulation frequency of books in eighteen subject areas of a small college library (Polley \& Marshall, 2015). Wikipedia's category structure and the Universal Decimal Classification system have been visualized in their entirety and compared (Salah et al., 2011). Ahn, Lin, Khoo and their collaborators have automatically assigned Dewey Decimal Classification (DDC) numbers to various digital libraries and have then visualized the DDC landscape based on co-assignment of class numbers between documents (Lin et al., 2015; Lin et al., 2017). This is an example of going beyond linked and hierarchical data and using an additional associative hook (co-assignment of class numbers) to more rigorously map a KOS. Klingemann used crowd-sourced tags from Flickr of images in books taken from the Internet Archives to create The Internet Archive's Map of Book Subjects (Klingemann, 2014). Benenson maps the overlap of cultural figures based on shared books they found influential (Benenson, 2012).

\section{Data}

On May 2, 2011, United States special forces killed Osama Bin Laden (OBL) in his compound in Abbottabad, Pakistan. In his possession were digital editions of English language books (BBC News, 2015). Amongst many other types of documents (letters, software and technical manuals, "Materials Regarding France," etc.), thirty-nine English language books are listed by Office of the Director of National Intelligence as having been found in the OBL compound (Office of the Director of National Intelligence, 2015). As this list of books has garnered considerable media attention (Boyer, 2015; Jacobson, 2015; Worland, 2015) but see also (Hersh, 2015; Sankin, 2015), it is worth providing a visual overview of the subject content of these books - some of which is not readily apparent from the titles. (E.g. The Taking of America 1-2-3, applicable subject heading: Kennedy, John F. (John Fitzgerald), 19171963 -- Assassination.). See complete OBL English language bibliography in Appendix 1. Thirty-six of these items have entries in WorldCat with accompanying subject headings and Library of Congress and Dewey Decimal classification numbers. See Appendix 2 for the three works without sufficient WorldCat data.

This combined data was used to create book-subject maps and tree maps of the English language books in OBL's possession. Thirty-six works produced 328 subject headings. See Table 1 for a breakdown of the subject types. In order to enhance the base map with meaningful thematic overlay, library holding count data was also harvested (and aggregated from duplicates). ${ }^{1}$ This additional data revealed the relative scarcity or popularity of individual books.

\footnotetext{
${ }^{1}$ Count data limited to the search categories: Books, Computer Files, Internet Resources, and Microforms (Archival Materials) (Excluded: Visual Materials, Serial Publications, Sound Recordings, Continually Updated Resources, Articles, Musical Scores, and Maps.)
} 
Table 1: Count of Subjects by Type

\begin{tabular}{|l|c|}
\hline \multicolumn{1}{|c|}{ Subject Type } & Count Of Subject Type \\
\hline \hline Descriptor: & 205 \\
\hline Geographic: & 71 \\
\hline Time: & 15 \\
\hline Named Corp: & 13 \\
\hline Named Conf: & 10 \\
\hline Genre/Form: & 8 \\
\hline Named Person: & 6 \\
\hline
\end{tabular}

\section{Methods}

\section{Disparity as to Amount of Subject Headings}

Not all WorldCat entries for the same work include the same amount of, or the same subject headings. Except as noted, subject headings were harvested from the WorldCat entries with the largest amount of "Libraries worldwide that own item." Similarly, different OCLC entries for the same work might have different metadata such as Library of Congress classification number. For instance, in the following case with Project MKULTRA, subject headings were harvested from the more expansive OCLC entry:

\section{Accession No: OCLC: 3735254 (Project MKULTRA)}

Descriptor: Behavior modification -- Research -- United States.

Behavior modification -- Research.

Named Corp: United States. Central Intelligence Agency.

United States. Central Intelligence Agency.

Geographic: United States.

LC: $\quad$ KF26.5

Accession No: OCLC: 808515317 (Project MKULTRA)

Descriptor: Behavior modification -- Research -- Moral and ethical aspects -- United States.

Descriptor: Human experimentation in psychology -- Moral and ethical aspects -- United States.

Descriptor: $\quad$ Abuse of administrative power -- United States.

Descriptor: Psychological torture -- Moral and ethical aspects -- United States.

Descriptor: $\quad$ Psychotropic drugs -- Research -- Moral and ethical aspects -- United States.

Descriptor: Brainwashing -- Research -- Moral and ethical aspects -- United States.

Descriptor: Informed consent (Medical law) -- United States.

Descriptor: Official secrets -- United States.

Descriptor: Medical ethics -- United States.

Descriptor: Behavior modification -- Law and legislation.

Descriptor: Behavior modification -- Research.

Named Corp: United States. Central Intelligence Agency. Office of Scientific Intelligence -Corrupt practices. 


\author{
Named Corp: United States. Central Intelligence Agency. \\ Geographic: United States. \\ LC: $\quad$ HV8599.U6
}

\title{
Omitted Subject Headings
}

All non-English language subject headings were omitted. As to Genre/Form subject headings, "form" type subject headings ("Electronic Books"; "Interviews") were omitted but "genre" type subject headings ("History") were retained.

\section{Deduplication}

Geographic: USA. Use: United States. Whenever there were more than one variants of a Named Person, the more specific one was retained and used (Perkins, John, 1945- Use: Perkins, John M., 1945-).

\section{Treemaps}

In addition to the subject headings on WorldCat, both Dewey and Library of Congress classificaiton numbers were harvested in order to produce Treemaps (Shneiderman, 1992) of the hiearchical classification data for the OBL network. Treemaps at three differing levels of specificity in the hierarchy were produced with the analytical and visualization software tool, Tableau.

\section{Original Book/Subject Network}

Figure 1 shows the Bin Laden book/subject network in its entirety as visualized using the network visualization software, Pajek (Batagelj \& Mrvar, 1998, 2017). The visualization was produced using the draw window and the original layout energy of the spring-force algorythm, Fruchterman-Reingold 2d (Fruchterman \& Reingold, 1991). To minimize subject and book nodes from occluding one another, nodes were repositioned by hand to make the image more legible. Yet, the network remains cluttered. However, it is interesting to see the six books that do not share subject headings with other books. These are refered to as isolates and there are six of them: (1) 2030 Spike, (2) Guerrilla Air Defense, (3) Handbook of International Law, (4) Necessary Illusions, (5) Secrets of the Federal Reserve, and (6) Unfinished Business. Ideally, these isolates will be connected in a principled manner to the main body of the map (greatest connected component) through either subsequent refinement of the subject headings or inclusion of the classification hierarchical structure. 
Peter A. Hook and Amanda Gantchev. 2017. Using Combined Metadata Sources to Visualize a Small Library (OBL's English Language Books).

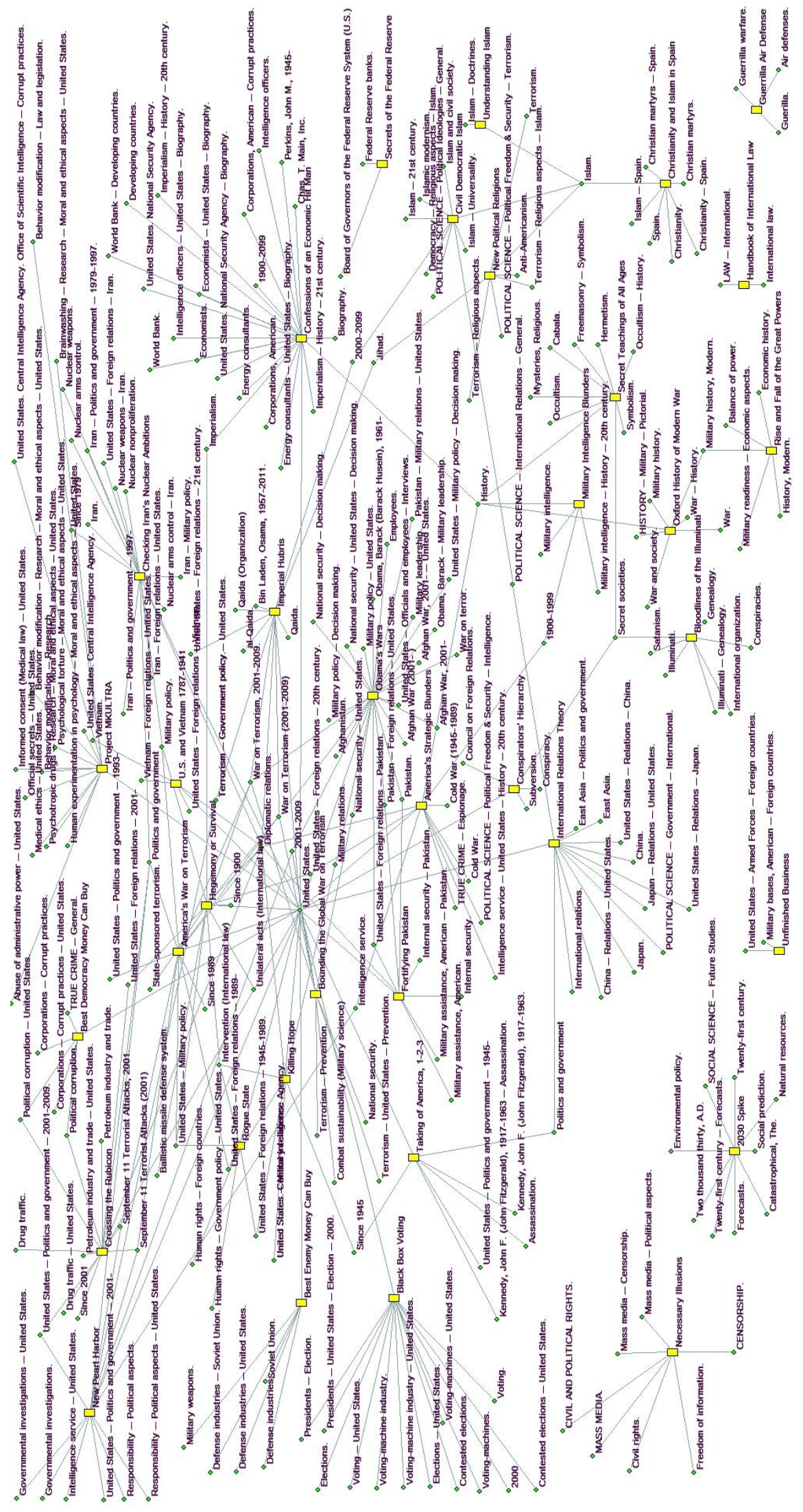

Figure 1: OBL Book / Subject Network (Original) 


\section{Subsequent Refinements}

Given, the unwieldly bulk of the original book/subject network, the authors propose the following principled steps to reduce the clutter while still preserving the subject matter insights provided by the metadata. (1) All periods "." should be removed as these are unnecessary to display on the map. (2) All near equivalent subject headings should be standardized. The similar, but non-identical subject assignments most likely resulted from different subject heading methodologies used by libraries around the world. The variants are interesting in a study of subject heading origin and use, but unnecessarily clutter the map. Consequently, they should be unified and controlled. See Table 2. This process was assisted by an alphabetical sort of the subject headings. (3) Subjects that appeared in all capital letters should be standardized to the appearance of the other subject headings (e.g. CENSORSHIP became Censorship).

Table 2: Near Variants of Subject Headings that were Unified and Controlled

\begin{tabular}{|l|c|l|c|}
\hline Preferred Subject Heading & $\begin{array}{c}\text { Original } \\
\text { Node } \\
\text { Number }\end{array}$ & Eliminated Subject Heading & $\begin{array}{c}\text { Original } \\
\text { Node } \\
\text { Number }\end{array}$ \\
\hline \hline Afghan War, 2001- & 45 & Afghan War (2001- ) & 43 \\
\hline al-Qaida & 48 & Qaida (Organization) & 207 \\
\cline { 3 - 4 } & 72 & Qaida. & 208 \\
\hline Cold War (1945-1989) & 75 & Cold War & 73 \\
\hline Conspiracies & 132 & Law -- International & 153 \\
\hline International law & 214 & $\begin{array}{l}\text { September 11 Terrorist Attacks } \\
\text { (2001) }\end{array}$ & 213 \\
\hline $\begin{array}{l}\text { September 11 Terrorist } \\
\text { Attacks, 2001 }\end{array}$ & 277 & War on Terrorism (2001-2009) & 276 \\
\hline War on Terrorism, 2001-2009 & & & \\
\hline
\end{tabular}

Perhaps most importantly, the faceted subject headings should be broken down into their individual nodes. This includes incidences in which the facets are separated by double hyphens "--" or by periods “." Additionally, use of "American" should be replaced by the separate node, "United States." See Table 3 and Figure 2.

Table 3: Examples of Unpacking the Faceted Subject Headings

\begin{tabular}{|c|c|c|c|c|c|c|c|}
\hline $\begin{array}{c}\text { Book } \\
\text { ID }\end{array}$ & \begin{tabular}{|c|} 
Book \\
Implicated
\end{tabular} & \begin{tabular}{|c|} 
Original \\
Faceted \\
Subject \\
Heading \\
ID \\
\end{tabular} & \begin{tabular}{||c|} 
Original \\
Faceted Subject \\
Heading
\end{tabular} & $\mid \begin{array}{c}\text { Implicated } \\
\text { Subject ID } \\
1\end{array}$ & \begin{tabular}{||c} 
Implicated \\
Subject \\
Heading 1
\end{tabular} & \begin{tabular}{||} 
Implicated \\
Subject ID \\
2
\end{tabular} & \begin{tabular}{|c} 
Implicated Subject \\
Heading 2
\end{tabular} \\
\hline 1 & 2030 Spike & 221 & \begin{tabular}{|l} 
Social Science -- \\
Future Studies
\end{tabular} & 282 & $\begin{array}{l}\text { Future } \\
\text { Studies }\end{array}$ & 221 & Social science \\
\hline 1 & 2030 Spike & 221 & $\begin{array}{l}\text { Social Science -- } \\
\text { Future Studies }\end{array}$ & 282 & $\begin{array}{l}\text { Future } \\
\text { Studies }\end{array}$ & 1 & 2030 Spike \\
\hline 25 & $\begin{array}{l}\text { Necessary } \\
\text { Illusions }\end{array}$ & 154 & $\begin{array}{l}\text { Mass media -- } \\
\text { Censorship }\end{array}$ & 62 & Censorship & 156 & Mass media \\
\hline 25 & Necessary & 155 & Mass media -- & 281 & Political & 156 & Mass media \\
\hline
\end{tabular}


Peter A. Hook and Amanda Gantchev. 2017. Using Combined Metadata Sources to Visualize a Small Library (OBL's English Language Books).

NASKO, Vol. 6. pp. 182-201.

\begin{tabular}{|c|c|c|c|c|c|c|c|}
\hline $\begin{array}{c}\text { Book } \\
\text { ID }\end{array}$ & $\begin{array}{c}\text { Book } \\
\text { Implicated }\end{array}$ & \begin{tabular}{|c|} 
Original \\
Faceted \\
Subject \\
Heading \\
ID \\
\end{tabular} & $\begin{array}{c}\text { Original } \\
\text { Faceted Subject } \\
\text { Heading }\end{array}$ & $\mid \begin{array}{c}\text { Implicated } \\
\text { Subject ID } \\
1\end{array}$ & $\begin{array}{c}\text { Implicated } \\
\text { Subject } \\
\text { Heading } 1\end{array}$ & \begin{tabular}{|c} 
Implicated \\
Subject ID \\
2
\end{tabular} & $\begin{array}{c}\text { Implicated Subject } \\
\text { Heading } 2\end{array}$ \\
\hline & Illusions & & Political aspects & & aspects & & \\
\hline 25 & $\begin{array}{l}\text { Necessary } \\
\text { Illusions }\end{array}$ & 155 & $\begin{array}{l}\text { Mass media -- } \\
\text { Political aspects }\end{array}$ & 281 & $\begin{array}{l}\text { Political } \\
\text { aspects }\end{array}$ & 25 & Necessary Illusions \\
\hline 35 & $\begin{array}{l}\text { Unfinished } \\
\text { Business }\end{array}$ & 160 & $\begin{array}{l}\text { Military bases, } \\
\text { American -- } \\
\text { Foreign } \\
\text { countries }\end{array}$ & 283 & $\begin{array}{l}\text { Foreign } \\
\text { countries }\end{array}$ & 264 & United States \\
\hline 35 & $\begin{array}{l}\text { Unfinished } \\
\text { Business }\end{array}$ & 160 & $\begin{array}{l}\text { Military bases, } \\
\text { American -- } \\
\text { Foreign } \\
\text { countries }\end{array}$ & 264 & $\begin{array}{l}\text { United } \\
\text { States }\end{array}$ & 160 & Military bases \\
\hline 35 & $\begin{array}{l}\text { Unfinished } \\
\text { Business }\end{array}$ & 240 & \begin{tabular}{|l} 
United States -- \\
Armed Forces -- \\
Foreign \\
countries
\end{tabular} & 283 & $\begin{array}{l}\text { Foreign } \\
\text { countries }\end{array}$ & 284 & Armed forces \\
\hline 35 & $\begin{array}{l}\text { Unfinished } \\
\text { Business }\end{array}$ & 240 & $\begin{array}{l}\text { United States -- } \\
\text { Armed Forces -- } \\
\text { Foreign } \\
\text { countries }\end{array}$ & 284 & $\begin{array}{l}\text { Armed } \\
\text { forces }\end{array}$ & 264 & United States \\
\hline 35 & $\begin{array}{l}\text { Unfinished } \\
\text { Business }\end{array}$ & 240 & $\begin{array}{l}\text { United States -- } \\
\text { Armed Forces -- } \\
\text { Foreign } \\
\text { countries }\end{array}$ & 283 & $\begin{array}{l}\text { Foreign } \\
\text { countries }\end{array}$ & 35 & Unfinished Business \\
\hline 35 & $\begin{array}{l}\text { Unfinished } \\
\text { Business }\end{array}$ & 240 & $\begin{array}{l}\text { United States -- } \\
\text { Armed Forces -- } \\
\text { Foreign } \\
\text { countries }\end{array}$ & 284 & $\begin{array}{l}\text { Armed } \\
\text { forces }\end{array}$ & 35 & Unfinished Business \\
\hline 35 & $\begin{array}{l}\text { Unfinished } \\
\text { Business }\end{array}$ & 240 & $\begin{array}{l}\text { United States -- } \\
\text { Armed Forces -- } \\
\text { Foreign } \\
\text { countries }\end{array}$ & 264 & $\begin{array}{l}\text { United } \\
\text { States }\end{array}$ & 35 & Unfinished Business \\
\hline
\end{tabular}

During the unpacking of the faceted subject headings, the need for two rules became clear. Rule 1: When all components of a faceted subject heading already exist as individual subject headings associated with the same work, merely delete the entire faceted subject heading. See Figure 3. Rule 2: When unpacking faceted subject headings, each of the individual facet nodes should be fully connected (forming a clique) with all of the other facet nodes in the original faceted subject heading AND connected to the work to which they have been assigned. See Figure 4. This insures that all of the component nodes are associated with each other and the work to which they were assigned in faceted form. 
Peter A. Hook and Amanda Gantchev. 2017. Using Combined Metadata Sources to Visualize a Small Library (OBL's English Language Books).
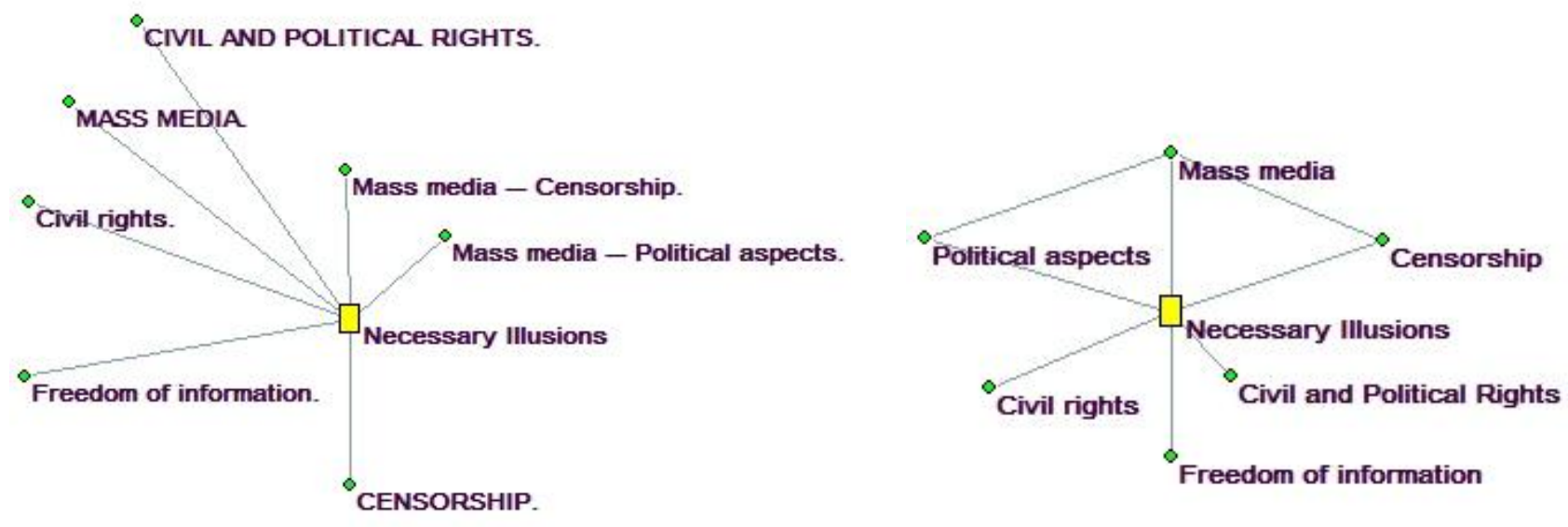

Figure 2: Modification of the Subject Headings Associated with Necessary Illusions

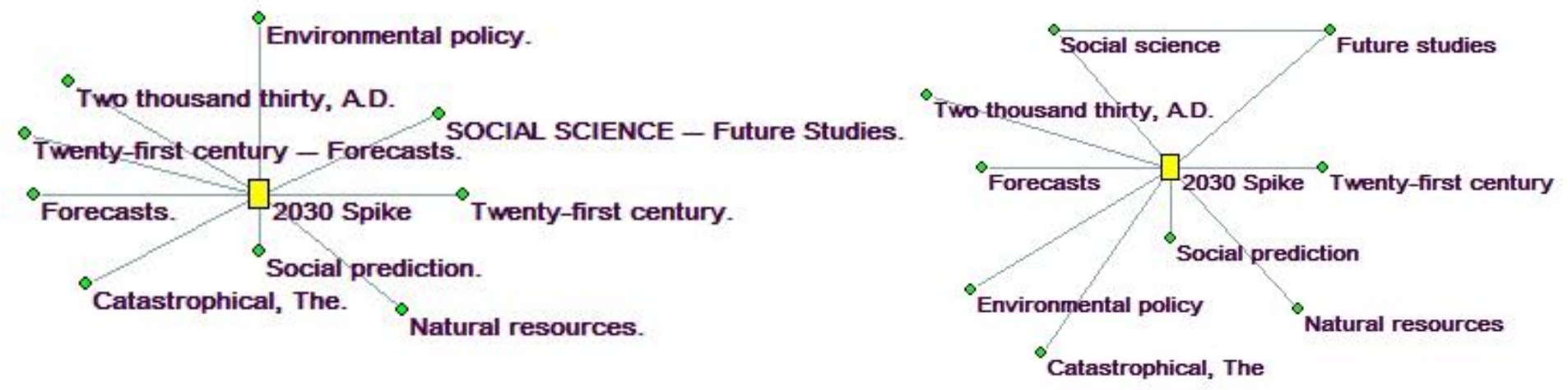

Figure 3: Modification of the Subject Headings Associated with 2030 Spike
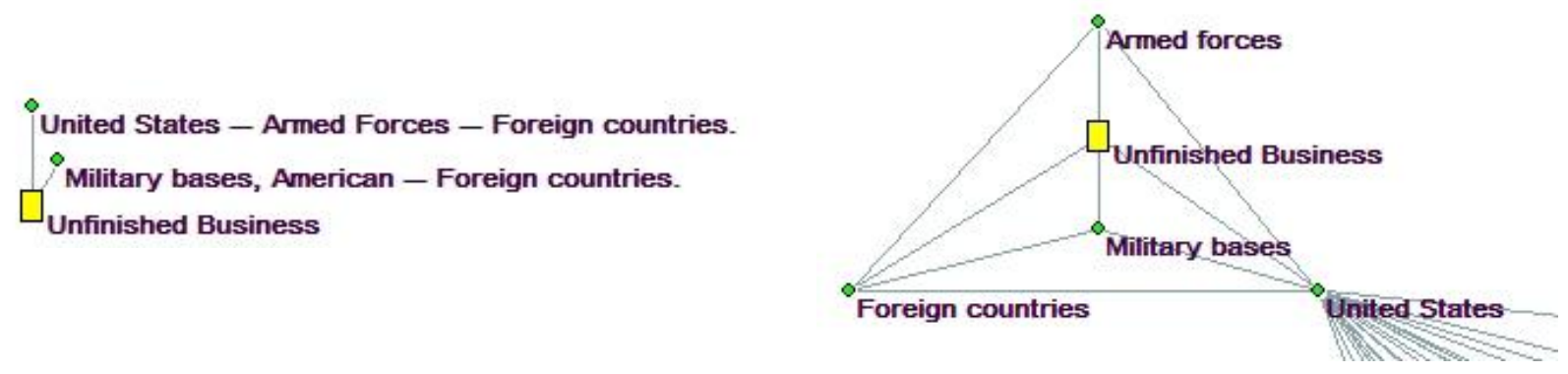

Figure 4: Modification of the Subject Headings Associated with Unfinished Business 
Peter A. Hook and Amanda Gantchev. 2017. Using Combined Metadata Sources to Visualize a Small Library (OBL's English Language Books).

NASKO, Vol. 6. pp. 182-201.

\section{Visualizing the Classification Hierarchy}

In addition to subject heading assignments, both Dewey Decimal and Library of Congress classification numbers were harvested for all thirty-six works that appeared in WorldCat. Schedules freely available over the Web were used to convert the class numbers to hierarchical breakdowns and then visualized using the Treemap (Shneiderman, 1992) algorithm as implemented in Tableau. The treemaps were enhanced with images of the front covers of the books obtained from WorldCat and Google Images. See Figures 5 through 7 for Dewey treemaps. See Appendix 3 for Library of Congress treemaps. Color has been maintained throughout based on the first level of the hierarchy.

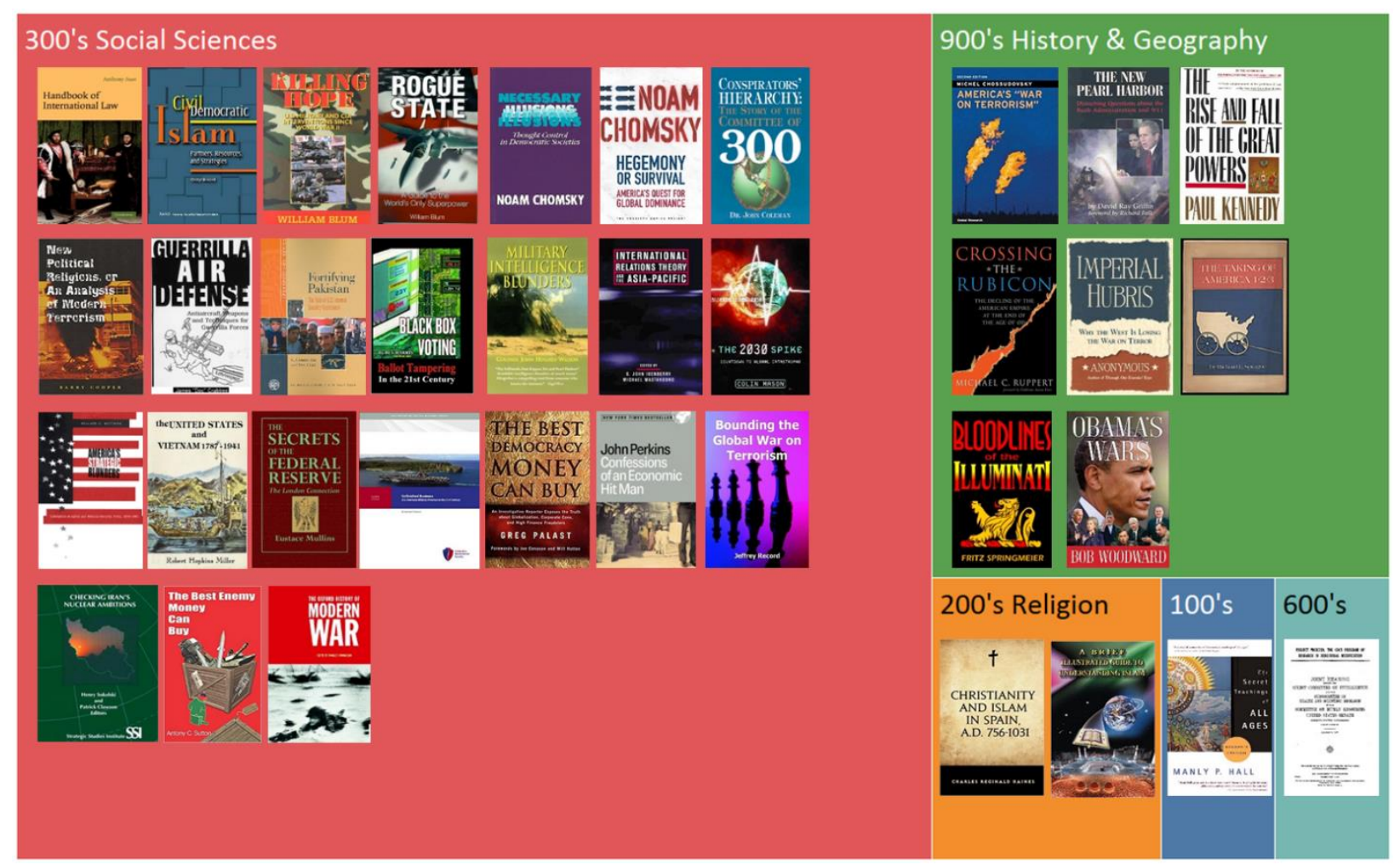

Figure 5: Dewey 22 Treemap First Summary 
Peter A. Hook and Amanda Gantchev. 2017. Using Combined Metadata Sources to Visualize a Small Library (OBL's English Language Books). NASKO, Vol. 6. pp. 182-201.

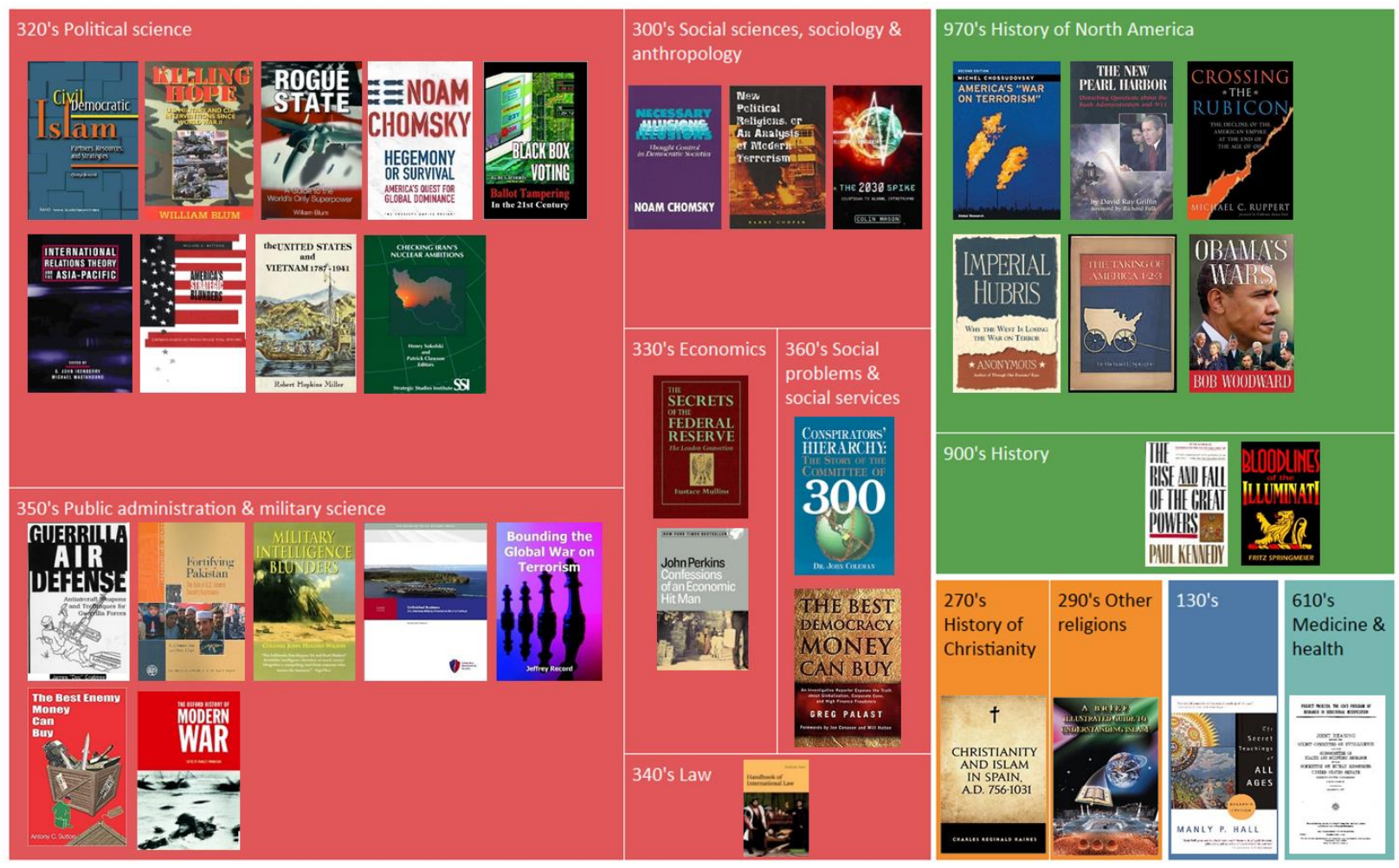

Figure 6: Dewey 22 Treemap Second Summary

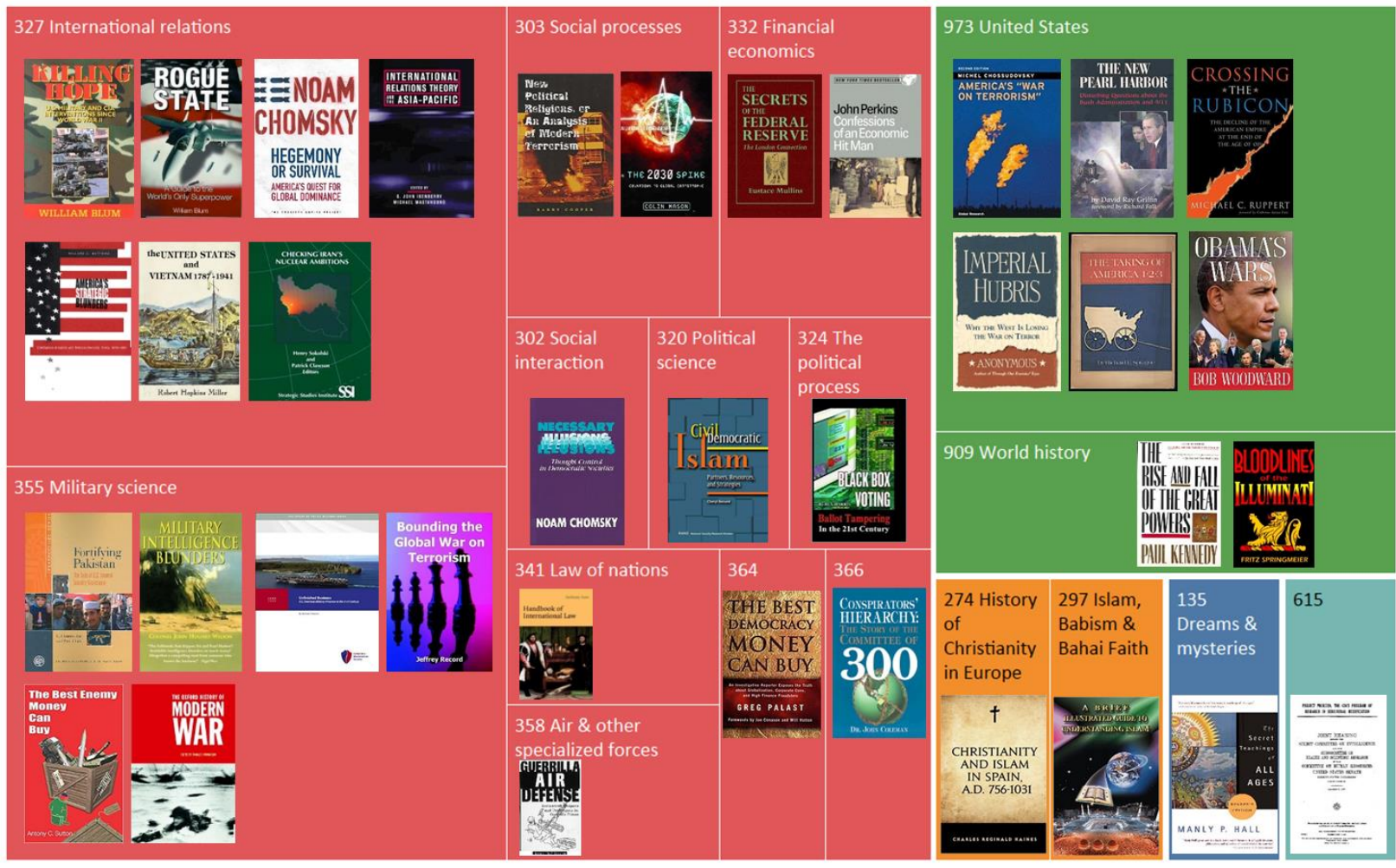

Figure 7: Dewey 22 Treemap Third Summary 


\section{Converting the Classification Hierarchy to Node Link Diagrams}

It is possible to conceptualize the hierarchy of classification systems as node link diagrams. As seen below in Figure 8, the first three summaries of the Dewey Decimal system are represented as nodes with the directional arrows pointing higher up in the hierarchy. The OBL books are placed at the end of these node link chains and represent the most specific instantiation of a particular concept. Additionally, the subtitles of the books (after the colon) are also linked to the book. Space limitations do not allow for long title strings to appear on the map. However, the subtitles appearing as separate subject nodes allow for this rich information to be conveyed in the compact space available on the map. 
Peter A. Hook and Amanda Gantchev. 2017. Using Combined Metadata Sources to Visualize a Small Library (OBL's English Language Books).

NASKO, Vol. 6. pp. 182-201.

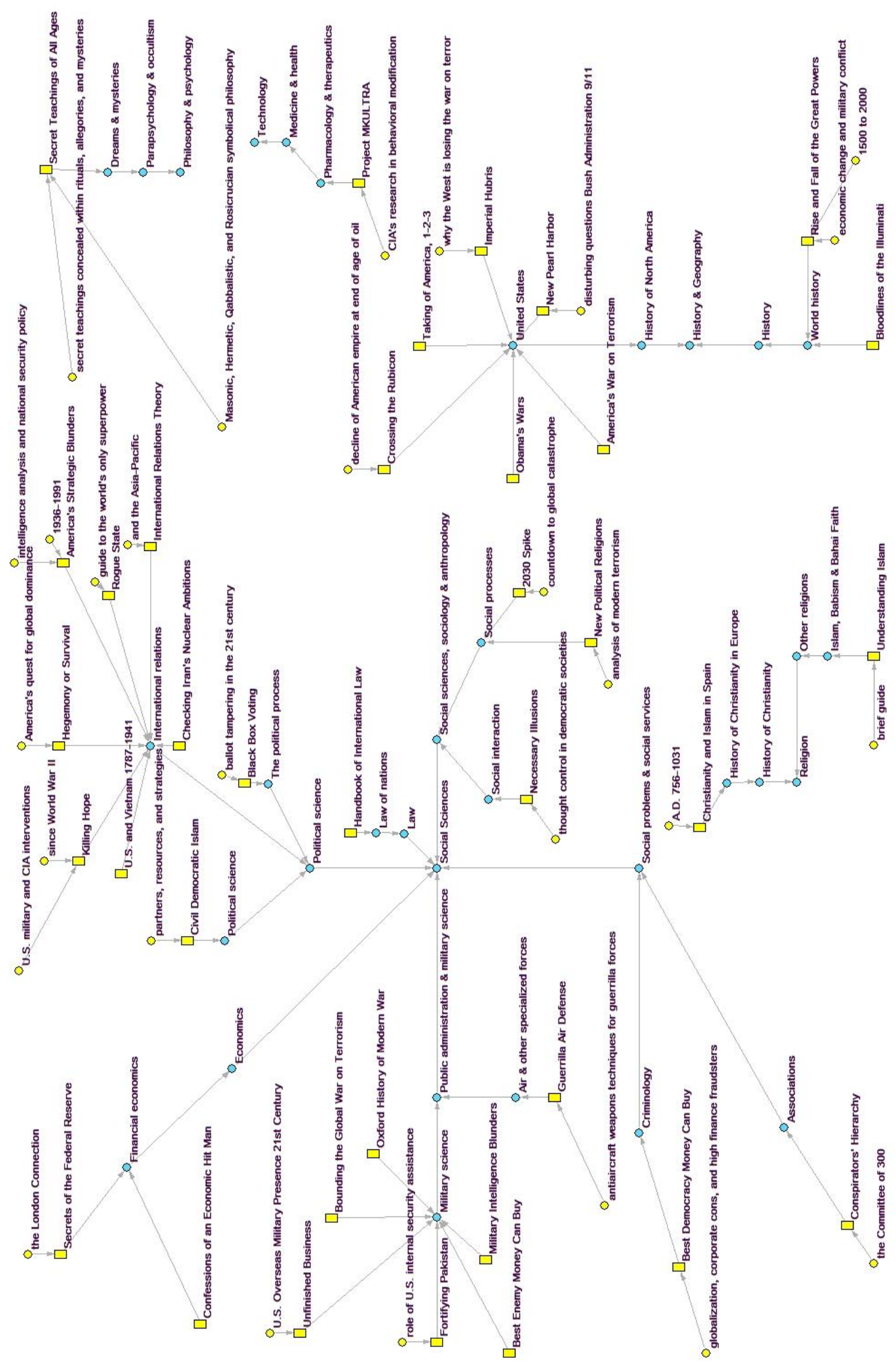

Figure 8: OBL Works as Dewey 22 Node Link Diagram 


\section{Metrics as to the Frequency Held}

Table 4 conveys how popular or rare the books are in the OBL library. Sometimes OBL acquired best sellers. At other times, he acquired scarce or niche items that are not widely held by WorldCat participating libraries. This data is one element that can be thematically overlain on the final OBL book / subject map by varying the size of the book nodes.

Table 4: Amount of Libraries Worldwide that Hold the OBL Works (According to WorldCat)

\section{RANK TITLE}

TOTAL HOLDINGS ON WORLDCAT

\begin{tabular}{|c|c|c|}
\hline 1 & Rise and Fall of the Great Powers & 4893 \\
\hline 2 & Obama's Wars & 2955 \\
\hline 3 & Best Democracy Money Can Buy & 2888 \\
\hline 4 & Confessions of an Economic Hit Man & 2877 \\
\hline 5 & Imperial Hubris & 2347 \\
\hline 6 & Civil Democratic Islam & 2092 \\
\hline 7 & 2030 Spike & 2042 \\
\hline 8 & Hegemony or Survival & 1898 \\
\hline 9 & New Political Religions & 1803 \\
\hline 10 & America's Strategic Blunders & 1341 \\
\hline 11 & Necessary Illusions & 1322 \\
\hline 12 & Oxford History of Modern War & 1263 \\
\hline 13 & Crossing the Rubicon & 1218 \\
\hline 14 & Secret Teachings of All Ages & 1107 \\
\hline 15 & International Relations Theory & 1083 \\
\hline 16 & New Pearl Harbor & 896 \\
\hline 17 & Handbook of International Law & 865 \\
\hline 18 & U.S. and Vietnam 1787-1941 & 683 \\
\hline 19 & Secrets of the Federal Reserve & 678 \\
\hline 20 & Rogue State & 475 \\
\hline 21 & Killing Hope & 465 \\
\hline 22 & Checking Iran's Nuclear Ambitions & 335 \\
\hline 23 & Bounding the Global War on Terrorism & 322 \\
\hline 24 & Fortifying Pakistan & 316 \\
\hline 25 & Christianity and Islam in Spain & 308 \\
\hline 26 & Military Intelligence Blunders & 262 \\
\hline 27 & Project MKULTRA & 204 \\
\hline 28 & Black Box Voting & 164 \\
\hline 29 & America's "War on Terrorism" & 88 \\
\hline 30 & Conspirators' Hierarchy & 71 \\
\hline 31 & Understanding Islam & 70 \\
\hline
\end{tabular}




\begin{tabular}{l|lc}
32 & Best Enemy Money Can Buy & 46 \\
33 & Taking of America, 1-2-3 & 12 \\
34 & Guerrilla Air Defense & 7 \\
35 & Bloodlines of the Illuminati & 6 \\
36 & Unfinished Business & 5 \\
37 & Al-Qaeda's Online Media Strategies & 1 \\
38 & In Pursuit of Allah's Pleasure & 0 \\
38 & Website Claims Steve Jackson Games Foretold 9/11
\end{tabular}

\section{Conclusions and Future work}

The metadata for the works reveal that OBL was very interested in his chief adversary, the United States. Presuming the books were actually read by him, he read about himself and the War on Terror. He read about the past international dealings of the United States. He read about conspiracy theories and the occult. He read about military science and international law. The book / subject network maps, the treemaps, and the node link diagrams of the works' embedded location in the classification structure serve to provide a quick overview to the library and reading interests of OBL that goes far beyond the list of works that appears on the Office of the Director of National Intelligence's website.

The proposed modifications of the OBL book / subject network must still be completed based on the principles and procedures outlined above. Additionally, the isolates have to be fully integrated into the knowledge map using the addition of the classification network. As to the representation of the classification network, the node size should be varied to reflect the level of the hierarchy-first summaries being the largest nodes. This pilot study has uncovered methodologies and best practices to produce large scale, integrated book / subject knowledge maps using the rich metadata of more than one knowledge organization system. 
Peter A. Hook and Amanda Gantchev. 2017. Using Combined Metadata Sources to Visualize a Small Library (OBL's English Language Books).

NASKO, Vol. 6. pp. 182-201.

\section{References}

Batagelj, V., \& Mrvar, A. (1998). Pajek: A program for large network analysis. Connections, 21(2), 4757.

Batagelj, V., \& Mrvar, A. (2017, Feb. 1). Pajek: analysis and visualization of large networks. Retrieved May 15, 2017, from http://mrvar.fdv.uni-lj.si/pajek/

BBC News. (2015, May 20). What was on Osama Bin Laden's bookshelf? BBC News Website. Retrieved from http://www.bbc.com/news/world-asia-32816412

Benenson, F. (2012, December 5). Data behind My Ideal Bookshelf. from http://fredbenenson.com/2012/12/05/the-data-behind-my-ideal-bookshelf/

Börner, K., Hardy, E., Herr, B., Holloway, T., \& Paley, W. B. (2007). Taxonomy visualization in support of the semi-automatic validation and optimization of organizational schemas. Journal of Informetrics, 1, 214-225.

Boyer, L. (2015, May 20). U.S. releases contents of Osama bin Laden's 'bookshelf'. U.S. News \& World Reports. Retrieved from http://www.usnews.com/news/articles/2015/05/20/us-releases-contentsof-osama-bin-ladens-bookshelf

Doms, A., \& Schroeder, M. (2005). GoPubMed: exploring PubMed with the Gene Ontology. Nucleic Acids Research, 33(Web Server issue), W783-W786.

Fruchterman, T. M. J., \& Reingold, E. M. (1991). Graph Drawing by Force-Directed Placement. Software, Practice and Experience, 21(11), 1129-1164.

Gleich, D. F. (2009, Summer). Library of Congress Subject Headings. from http://cads.stanford.edu/projects/presentations/summer-2009/gleich-lcsh-presentation.pdf

gopubmed. Retrieved Feb. 20, 2017, from http://www.gopubmed.com/web/gopubmed/

Hersh, S. M. (2015, May 21). Killing of Osama bin Laden. London Review of Books, 37, 3-12.

Jacobson, M. (2015, May 27). Conspiracist's guide to Osama bin Laden's bookshelf. New York Magazine.

Klingemann, M. (2014, October 18). The Internet Archive's Map of Book Subjects. Version 2.0. from http://incubator.quasimondo.com/internetarchive/InternetArchiveBookSubjectsMap.html

Lin, X., Khoo, M., Ahn, J.-w., Binding, C., Tudhope, D., Jones, H., \& Massam, D. (2015, 1-4 September). DDC visual interface for metadata exploration. Paper presented at the International Conference on Dublin Core and Metadata Applications, São Paulo, Brazil.

Lin, X., Khoo, M., Ahn, J.-w., Tudhope, D., Binding, C., Massam, D., \& Jones, H. (2017). Mapping metadata to DDC classification structures for searching and browsing. International Journal on Digital Libraries, 18(1), 25-39.

Office of the Director of National Intelligence. (2015). Bin Laden's bookshelf. Retrieved Feb. 19, 2017, from https://www.dni.gov/index.php/resources/bin-laden-bookshelf

Polley, D. E., \& Marshall, B. (2015). Visualizing Library Collection Data (Wabash College).

Salah, A. A. A., Gao, C., Scharnhorst, A., \& Suchecki, K. (2011). Design vs. emergence: visualisation of knowledge orders. In K. Börner \& M. J. Stamper (Eds.), Places \& Spaces: Mapping Science: 7th Iteration (2011): Science Maps as Visual Interfaces to Digital Libraries.

Sankin, A. (2015, May 20). Osama bin Laden was apparently reading a 9/11 truther book. The Daily Dot. Retrieved from http://www.dailydot.com/layer8/bin-ladins-bookshelf-911-truth/

Shneiderman, B. (1992). Tree visualization with tree-maps: 2-d space-filling approach. $A C M$ Transactions on Graphics (TOG), 11(1), 92-99.

Stanford University's CADS, \& LOC's Office of Strategic Initatives. (2009a, Sept. 5). LCSH Galaxy. from http://cads.stanford.edu/lcshgalaxy/

Stanford University's CADS, \& LOC's Office of Strategic Initatives. (2009b, Sept. 5). LCSH Galaxy, More Information. from http://cads.stanford.edu/lcshgalaxy/more.html

Worland, J. (2015, May 20). 8 surprising titles found on Osama Bin Laden's bookshelf. Time. 


\section{Appendix 1 - English Language Books OBL’s Bookshelf}

Website Claims Steve Jackson Games Foretold 9/11. (2004). Retrieved Dec. 12, 2016, from http://icv2.com/articles/games/view/4738/website-claims-steve-jackson-game-foretold-9-11

Aust, A. (2005). Handbook of international law (1st ed.). Cambridge, UK: Cambridge University Press.

Benard, C. (2003). Civil democratic Islam: partners, resources, and strategies. Santa Monica, California: RAND, National Security Research Division.

Blum, W. (1995). Killing hope: U.S. military and CIA interventions since World War II (1st ed.). Monroe, Maine: Common Courage Press.

Blum, W. (2000). Rogue state: a guide to the world's only superpower (1st ed.). Monroe, Maine: Common Courage Press.

Chomsky, N. (1989). Necessary illusions: thought control in democratic societies (1st ed.). Boston: South End Press.

Chomsky, N. (2003). Hegemony or survival: America's quest for global dominance (1st ed.). New York: Metropolitan Books.

Chossudovsky, M. (2005). America's "war on terrorism" (2nd ed.). Montreal: Global Research.

Coleman, J. (1992). Conspirators' hierarchy: the story of the Committee of 300 (First ed.). Carson City, Nevada: America West Publishers.

Cooper, B. (2004). New political religions, or, an analysis of modern terrorism. Columbia, Missouri: University of Missouri Press.

Crabtree, J. D. (1996). Guerrilla air defense: antiaircraft weapons and techniques for guerrilla forces. Boulder, Colorado: Paladin Press.

Fair, C. C., \& Chalk, P. (2006). Fortifying Pakistan: the role of U.S. internal security assistance. Washington, D.C.: United States Institute of Peace Press.

Griffin, D. R. (2004). New Pearl Harbor: disturbing questions about the Bush administration and 9/11 (1st ed.). Northampton, Massachusettes: Olive Branch Press.

Haines, C. R. (1889). Christianity and Islam in Spain, A.D. 756-1031. London: K. Paul, Trench.

Hall, M. P. (2003, 1928). Secret teachings of all ages: an encyclopedic outline of Masonic, Hermetic, Qabbalistic, and Rosicrucian symbolical philosophy: being an interpretation of the secret teachings concealed within the rituals, allegories, and mysteries of the ages (Reader's ed.). New York: Jeremy P. Tarcher/Penguin.

Harris, B., Allen, D., \& Alexander, L. (2003). Black box voting: ballot tampering in the 21st century. High Point, North Carolina: Plan Nine Pub.

Hughes-Wilson, J. (1999). Military intelligence blunders (1st Carroll \& Graf ed. ed.). New York: Carroll \& Graf.

Ibrahim, A. (1996). Brief guide to understanding Islam. Houston, Texas: Darussalam, Publishers \& Distributors.

Ibrahim, N., Maajid, A. A., \& Darbaalah, E. U. D. (Producer). (1984, Dec. 12, 2016). In pursuit of Allah's pleasure. Retrieved from http://www.khilafahbooks.com/in-pursuit-of-allahs-pleasure-by-drnaaha-ibrahim-asim-abdul-maajid-essam-ud-deen-darbaalah/

Ikenberry, G. J., \& Mastanduno, M. (Eds.). (2003). International relations theory and the Asia-Pacific. New York: Columbia University Press.

Kennedy, P. M. (1988). Rise and fall of the great powers: economic change and military conflict from 1500 to 2000. New York: Random House.

Mason, C. (2003). 2030 spike: countdown to global catastrophe. Sterling, Virginia: Earthscan Publications.

Matthias, W. C. (2001). America's strategic blunders: intelligence analysis and national security policy, 1936-1991. University Park, Pennsylvania: Pennsylvania State University Press.

Miller, R. H. (1990). United States and Vietnam, 1787-1941. Washington, D.C.: National Defense University Press. 
Mullins, E. (1983). Secrets of the Federal Reserve: the London Connection (1st ed.). Staunton, Virginia: Bankers Research Institute.

O'Hanlon, M. (2008). Unfinished business: U.S. overseas military presence in the 21st century. Washington, D.C.: Center For A New American Security.

Palast, G. (2002). Best democracy money can buy: an investigative reporter exposes the truth about globalization, corporate cons, and high finance fraudsters. London: Pluto Press.

Perkins, J. (2004). Confessions of an economic hit man (1 st ed.). San Francisco: Berrett-Koehler Publishers.

Record, J. (2003). Bounding the global war on terrorism Carlisle, Pennsylvania: Strategic Studies Institute, U.S. Army War College.

Rogan, H. (2007). Al-Qaeda's online media strategies: from Abu Reuter to Irhabi 007. (Master Thesis), University Of Oslo. Retrieved from https://www.ffi.no/no/Rapporter/07-02729.pdf

Ruppert, M. C. (2004). Crossing the Rubicon: the decline of the American empire at the end of the age of oil. Gabriola, British Columbia: New Society Publishers.

Scheuer, M. (2004). Imperial hubris: why the West is losing the war on terror (1st ed.). Washington, D.C.: Brassey's.

Sokolski, H. D., \& Clawson, P. (2004). Checking Iran's nuclear ambitions. Carlisle, Pennsylvania: Strategic Studies Institute, U.S. Army War College.

Sprague, R. E. (1976). Taking of America, 1-2-3 (1st ed.). Hartsdale New York: Richard Sprague (self published).

Springmeier, F. (1999). Bloodlines of the illuminati (1st ed.). Westminster, Colorado: Ambassador House. Sutton, A. C. (1986). Best enemy money can buy. Billings, MontANA: Liberty House Press.

Townshend, C. (2000). Oxford history of modern war. New York: Oxford University Press.

United States Congress Senate Select Committee on Intelligence, \& United States Congress Senate Committee on Human Resources. (1977). Project MKULTRA, the CIA's program of research in behavioral modification: joint hearing before the Select Committee on Intelligence and the Subcommittee on Health and Scientific Research of the Committee on Human Resources, United States Senate, Ninety-fifth Congress, first session, August 3, 1977. Washington D. C.: Government Printing Office.

Woodward, B. (2010). Obama's wars (1st Simon \& Schuster hardcover ed.). New York: Simon \& Schuster. 
Peter A. Hook and Amanda Gantchev. 2017. Using Combined Metadata Sources to Visualize a Small Library (OBL's English Language Books).

NASKO, Vol. 6. pp. 182-201.

\title{
Appendix 2 - English Language Books Without WorldCat Entries or WorldCat Entries with Insufficient Metadata
}

Website Claims Steve Jackson Games Foretold 9/11. (2004). Retrieved Dec. 12, 2016, from http://icv2.com/articles/games/view/4738/website-claims-steve-jackson-game-foretold-9-11 (Not a book but a website.)

Ibrahim, N., Maajid, A. A., \& Darbaalah, E. U. D. (Producer). (1984, Dec. 12, 2016). In pursuit of Allah's pleasure. Retrieved from http://www.khilafahbooks.com/in-pursuit-of-allahs-pleasure-by-drnaaha-ibrahim-asim-abdul-maajid-essam-ud-deen-darbaalah/

"This book, "In Pursuit of Allah's Pleasure" is the translation of a book titled: "Al-Meethaaq AlAml Al-Islami" (The Charter for Islamic Work) written by three scholars: Dr. Naajeh Ibrahim, Asim Abdul-Majid and Esaam-ud-Deen Darbaalah and released from behind the bars of Liman Turrah Prison, Egypt, in February 1984. The checking of this book was carried out by Dr. Sheikh Umar Abdur Rahman, currently serving a life sentence in the USA, for no other reason than upholding the truth.” (P. 2).

Rogan, H. (2007). Al-Qaeda's online media strategies: from Abu Reuter to Irhabi 007. (Master's Thesis), University Of Oslo. Retrieved from https://www.ffi.no/no/Rapporter/07-02729.pdf

\begin{abstract}
"Abstract: This study examines the online media campaign of the global jihadist movement. It seeks to determine whether al-Qaeda has developed a strategy for its media operations, and to what extent the jihadist media operators adhere to such a strategy. Drawing on primary sources from jihadist websites, the study identifies a number of recommendations about the use of media offered by jihadist strategists. The study goes on to examine the jihadist media companies and the material they produce and distribute online. Analyzing online jihadist media material including text, audio and video the study seeks to identify primarily the modus operandi of the media campaign, target audiences, and strategic goals of communication. The study finds that the Internet, which allows the jihadists to exercise ownership and control over mass media outlets, has a wider functionality than mainstream media. Allowing dispersed groups and individuals to participate in the media jihad, the Internet also provides for increased quantity, diversity and decentralization of the campaign. While the jihadist online media campaign so far seems to have targeted mostly supporters of the global jihadist movement, a current trend points to increasing efforts to reach new groups, and specifically the West. This study offers a comparison between the jihadist strategic recommendations and the actual jihadist use of the Internet as a media channel, and finds a certain degree of coherence between the two. Yet, as both recommendations and media activity are multi-faceted, the study concludes that there in fact exists a number of strategies, leading to a host of jihadist online media campaigns cohabitating the web. Although the study shows that the jihadists use also other media channels than the Internet, the online jihadist media campaign is in fact growing and frequently opening new fronts, thus pointing to a jihadist perception of the Internet as a purposeful vehicle for strategic communication. (OCLC: 702141365)."
\end{abstract}


Peter A. Hook and Amanda Gantchev. 2017. Using Combined Metadata Sources to Visualize a Small Library (OBL's English Language Books).

NASKO, Vol. 6. pp. 182-201.

\section{Appendix 3 - Library of Congress Treemaps with Book Images}

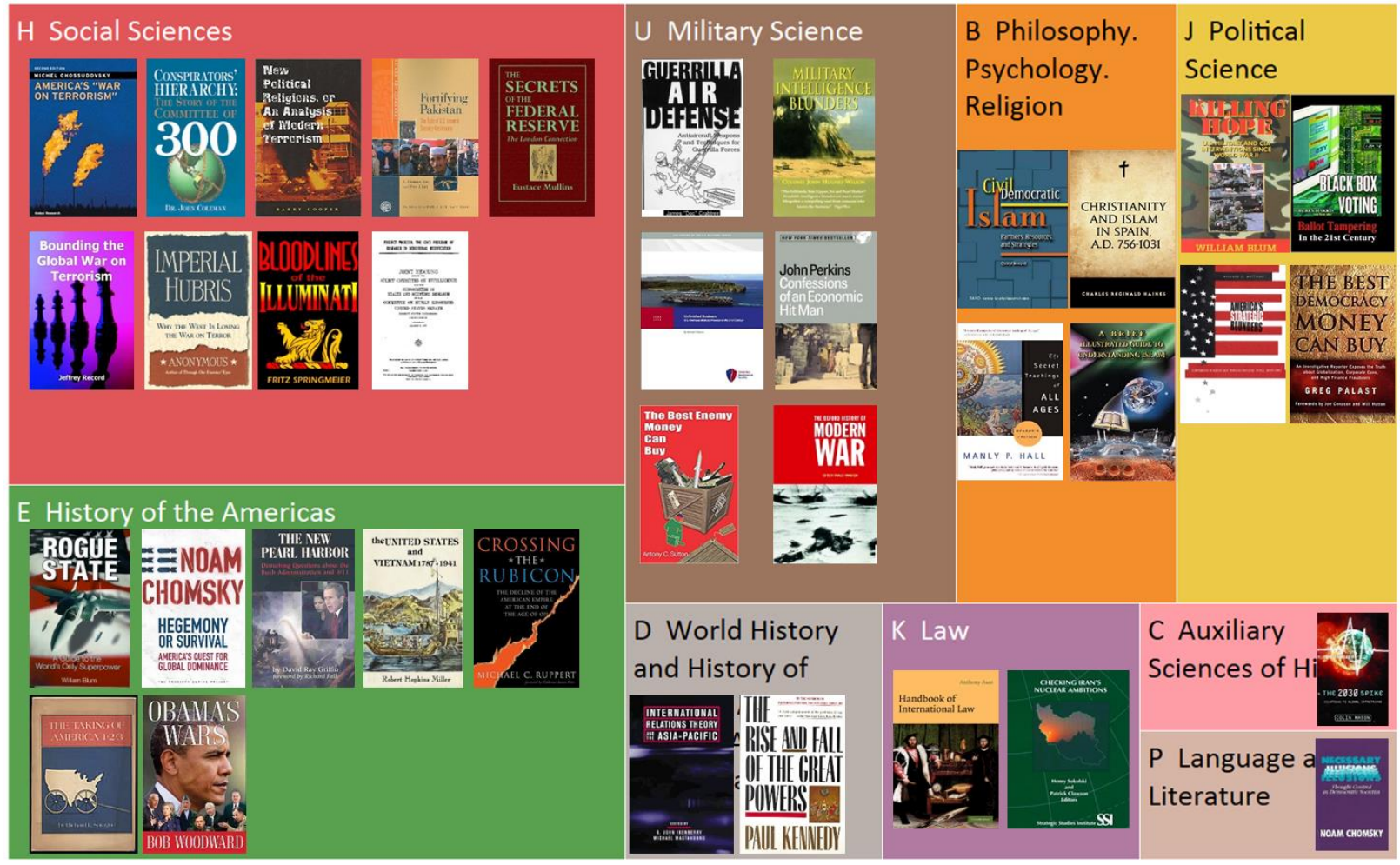

Library of Congress Basic Classes

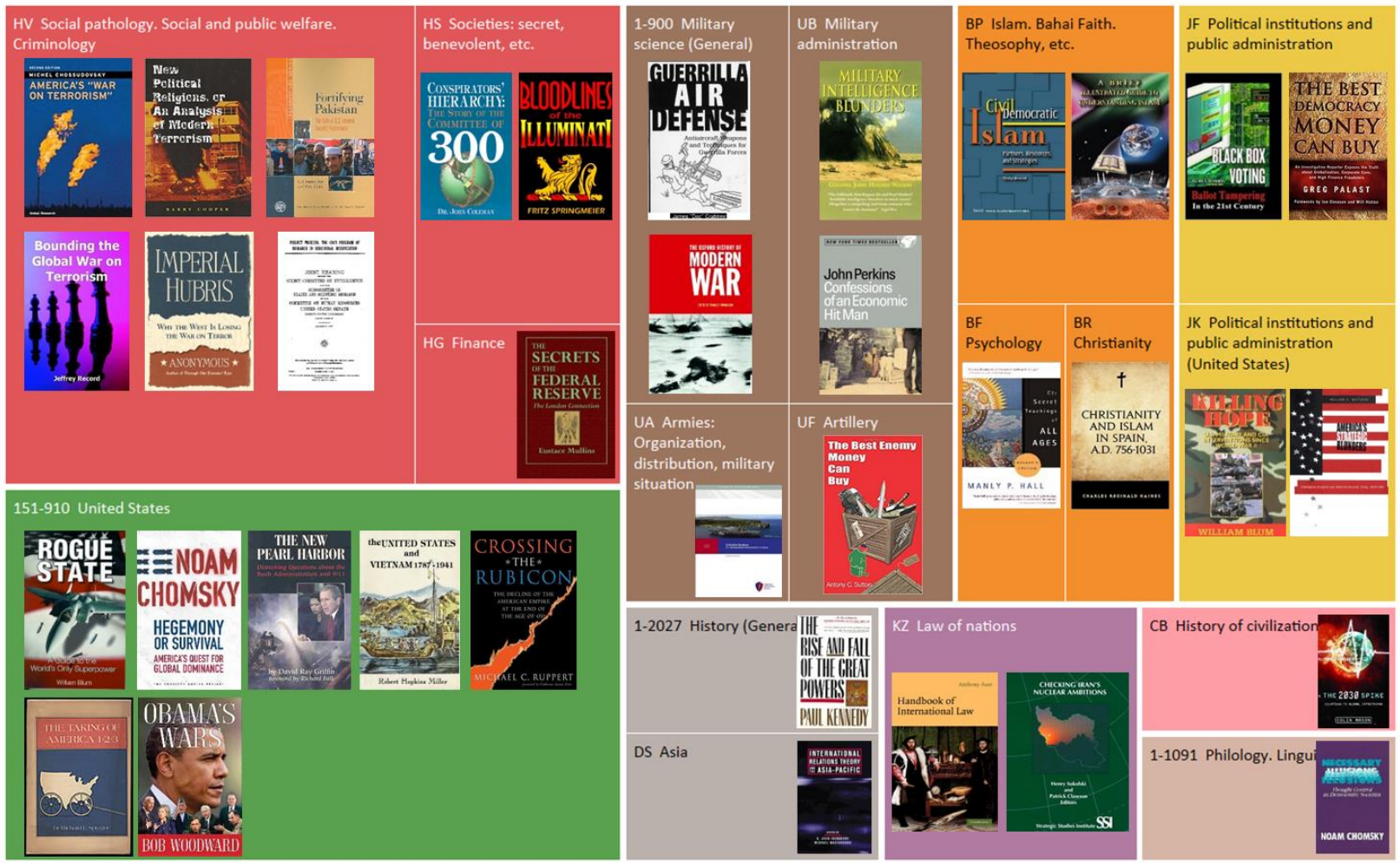

Library of Congress First Subclass 
Peter A. Hook and Amanda Gantchev. 2017. Using Combined Metadata Sources to Visualize a Small Library (OBL's English Language Books). NASKO, Vol. 6. pp. 182-201.

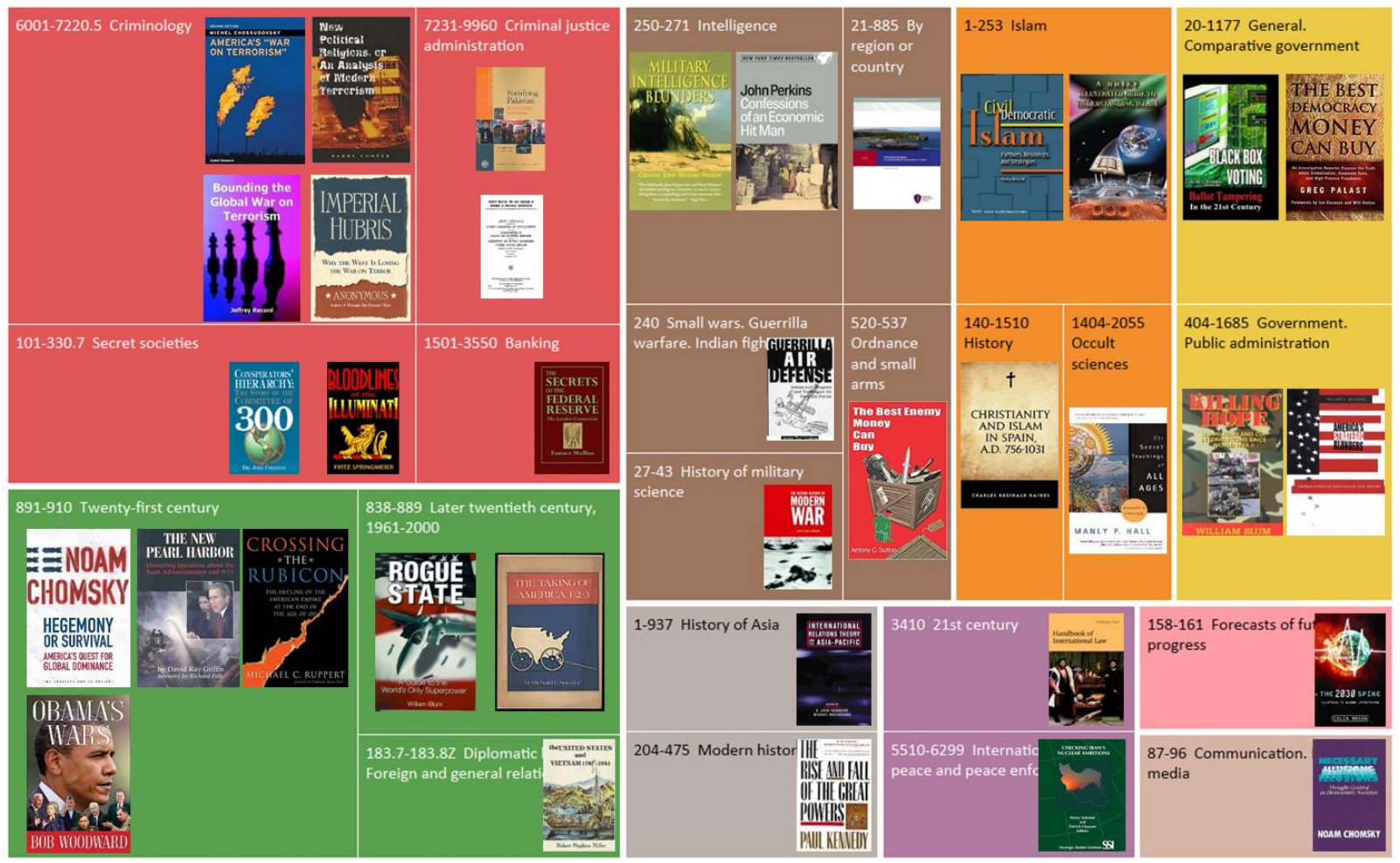

Library of Congress Third Level 